\title{
Development of a Novel Benzimidazole-Based Probe and Portable Fluorimeter for the Detection of Cysteine in Human Urine
}

\author{
Gyu Seong Yeom ${ }^{1,+}$, In-ho Song ${ }^{1,+}$, Shrikant Dashrath Warkad ${ }^{2}$, Pramod B. Shinde ${ }^{3}$ (D) Taewoon Kim ${ }^{4}$, \\ Seong-min Park ${ }^{1}$ and Satish Balasaheb Nimse ${ }^{1, * \mathbb{D}}$
}

1 Institute of Applied Chemistry and Department of Chemistry, Hallym University, Chuncheon 24252, Korea; m21019@hallym.ac.kr (G.S.Y.); songin-ho@hallym.ac.kr (I.-h.S.); psm3561@naver.com (S.-m.P.)

2 Biometrix Technology, Inc., 2-2 Bio Venture Plaza 56, Chuncheon 24232, Korea; shrikant@bmtchip.com

3 Natural Products \& Green Chemistry Division, CSIR—Central Salt and Marine Chemicals Research Institute (CSIR-CSMCRI), Council of Scientific and Industrial Research (CSIR),

Bhavnagar 364002, Gujarat, India; pramodshinde@csmcri.res.in

4 School of Software, Hallym University, Chuncheon 24252, Korea; taewoon@hallym.ac.kr

* Correspondence: satish_nimse@hallym.ac.kr

+ These authors contributed equally to this work.

Citation: Yeom, G.S.; Song, I.-h.;

Warkad, S.D.; Shinde, P.B.; Kim, T.;

Park, S.-m.; Nimse, S.B. Development of a Novel Benzimidazole-Based Probe and Portable Fluorimeter for the Detection of Cysteine in Human

Urine. Biosensors 2021, 11, 420.

https://doi.org/10.3390/

bios11110420

Received: 16 September 2021

Accepted: 25 October 2021

Published: 26 October 2021

Publisher's Note: MDPI stays neutral with regard to jurisdictional claims in published maps and institutional affiliations.

Copyright: (C) 2021 by the authors. Licensee MDPI, Basel, Switzerland. This article is an open access article distributed under the terms and conditions of the Creative Commons Attribution (CC BY) license (https:/ / creativecommons.org/licenses/by/ $4.0 /)$.

\begin{abstract}
The measurement of cysteine in human urine and live cells is crucial for evaluating biological metabolism, monitoring and maintaining the immune system, preventing tissue/DNA damage caused by free radicals, preventing autoimmune diseases, and diagnosing disorders such as cystinuria and cancer. A method that uses a fluorescence turn-on probe and a portable fluorescence spectrometer device are crucial for highly sensitive, simple, rapid, and inexpensive cysteine detection. Herein, we present the synthesis and application of a benzimidazole-based fluorescent probe (ABIA) along with the design and development of a portable fluorescence spectrometer device (CysDDev) for detecting cysteine in simulated human urine. ABIA showed excellent selectivity and sensitivity in detecting cysteine over homocysteine, glutathione, and other amino acids with the response time of $1 \mathrm{~min}$ and demonstrated a detection limit of $16.3 \mathrm{nM}$ using the developed CysDDev. Further, ABIA also demonstrated its utility in detecting intracellular cysteine, making it an excellent probe for bio-imaging assay.
\end{abstract}

Keywords: cysteine; biothiols; cystinuria; portable; fluorimeter; bio-imaging; cancer

\section{Introduction}

Biothiols such as cysteine (Cys), homocysteine (Hcy), and glutathione (GSH) play a vital role in numerous biological reactions [1-6]. It is important to note that among other biothiols, Cys deficiency exhibits several disorders, including edema, liver damage, muscle and fat loss, narcolepsy, skin damage, and weakness [7-9]. On the other hand, elevated cysteine levels are often correlated with cystinuria, a metabolic disorder characterized by the urinary loss of amino acids including Cys, arginine, ornithine, and lysine [10]. Therefore, measuring Cys in human urine and live cells is crucial for evaluating biological metabolism, monitoring and maintaining the immune system, preventing tissue/DNA damage caused by free radicals, preventing autoimmune diseases, and diagnosing disorders such as cystinuria and cancer.

There have been tremendous advances in developing methods for detecting biothiols in serum and live cells [11-14]. The development of fluorescent probes for detecting Cys has attracted significant attention from the broader scientific community [15-18]. The simplicity, high sensitivity and selectivity, and suitability for noninvasive and real-time detection are the significant advantages of methods based on fluorescent probes [19-22]. Though there are numerous reports on mechanistically different fluorescent probes for 
detecting biothiols [23-26], only a few have been applied to simultaneously detect Cys in human urine and live-cell imaging [27-29]. Therefore, using a fluorescent probe that can detect Cys in human urine and live cells can result in an excellent method for diagnosing cystinuria and Cys-related disorders [30].

There have been several reports on the colorimetric detection of Cys using paperbased devices [31,32]. However, proteins and large quantities of amino acids can interfere in color development reactions. The other disadvantage of paper-based devices is a higher limit of detection (LOD) $[33,34]$. Hence, paper-based devices can only provide qualitative information on urinary cysteine. Further, the fluorescence-based detection of Cys in biological fluids is advantageous over other methods due to its simple operating procedure, high sensitivity and selectivity for Cys in the presence of other proteins and amino acids, lower LOD, and the possibility of developing a portable device applicable in point-of-care settings.

Herein, we report on developing and applying a Cys specific fluorescent probe and the portable device for detecting cysteine in urine. The probe ABIA (2-(anthracen-9-yl)-5methyl-1H-benzo[d]imidazole-acrylamide), an organic dye, was prepared in a two-step reaction and was evaluated as the target probe for biothiols. ABIA demonstrated excellent selectivity for Cys over other biothiols and amino acids, with a response time of a mere $1 \mathrm{~min}$. The application of ABIA in live-cell imaging was evaluated by inverted fluorescence microscopy in a lung cancer cell line (A549), proving that ABIA as a suitable tool for tracking Cys in vitro. Its applicability in detecting Cys in live cells and simulated urine prompted us to develop a portable fluorimeter. The design and development of Cys detection device (CYsDDev) is also elaborated upon here. ABIA and CysDDev allow the detection of Cys in simulated urine, with a LOD of $16.3 \mathrm{nM}$.

\section{Materials and Methods}

\subsection{Materials and Instrumentation}

Reagents and required chemicals were procured either from Sigma-Aldrich (Seoul, Korea) or TCI (Seoul, Korea) and were used as received unless stated otherwise. The simulated urine (product code, 84 0679) was obtained from Biozoa Biological Supply Company (Seoul, Korea). The reactions were conducted under an inert atmosphere (argon gas). Completion of the reaction was monitored using thin-layer chromatography (TLC) by visualizing the plates under UV light (254 nm). DMSO-d6 was used as a solvent to characterize synthesized compounds by ${ }^{1} \mathrm{H}$ - and ${ }^{13} \mathrm{C}-\mathrm{NMR}$ spectroscopy on a Jeol FT-NMR spectrometer (400 MHz; JEOL, Tokyo, Japan). The chemical shifts $(\delta)$ and the coupling constants $(\mathrm{J})$ were reported as ppm and Hz, respectively. The Shimadzu UV-24500 (Shimadzu, Tokyo, Japan) spectrometer and Agilent Cary Eclipse fluorescence spectrophotometer (Agilent Technologies, Santa Clara, CA, USA) were used to record UV-visible spectra and fluorescence emission spectra, respectively. A JMS-700 MStation Mass Spectrometer (JEOL, Tokyo, Japan), a microplate Reader Spectramax Plus 384 (Molecular Devices, San Jose, CA, USA), and a confocal laser scanning microscope (Carl Zeiss LSM710, Osnabrück, Germany) were also used in the present study. The material for 3D printing and the electronic components required for the development of CysDDev were procured from Devicemart (Seoul, Korea) and Mouser Electronics (Seoul, Korea). A CUBICON Single Plus 320C (Jungwon, Korea) 3D printer was used to fabricate various parts and the body of CysDDev.

\subsection{Synthesis of Compound 3 (2-(Anthracen-9-yl)-5-methyl-1H-benzo[d]imidazole)}

A solution of anthracene-9-carbaldehyde $(0.84 \mathrm{~g}, 4.07 \mathrm{mmol})$ in ethanol $(10 \mathrm{~mL})$ was slowly added dropwise to a solution of 4-methylbenzene-1,2-diamine ( $0.5 \mathrm{~g}, 4.09 \mathrm{mmol})$ in ethanol $(20 \mathrm{~mL})$ with a dropping funnel for $2 \mathrm{~h}$. Then, the reaction mixture was continually stirred under air at room temperature until the completion of the reaction. The progress of the reaction was monitored by TLC using an ethyl acetate:hexanes (3:7) mixture. The precipitated product was filtered. The filter cake was washed with three aliquots of $10 \mathrm{~mL}$ 
ethanol followed by vacuum drying to obtain the final product: beige-colored powder. Yield: $1.01 \mathrm{~g}(80 \%) .{ }^{1} \mathrm{H}-\mathrm{NMR}\left(400 \mathrm{MHz}, \mathrm{DMSO}-d_{6}\right) \delta 12.88(\mathrm{~s}, 1 \mathrm{H}), 8.84(\mathrm{~s}, 1 \mathrm{H}), 8.21(\mathrm{~d}$, $\mathrm{J}=8.4 \mathrm{~Hz}, 2 \mathrm{H}), 7.69(\mathrm{~d}, \mathrm{~J}=8.7 \mathrm{~Hz}, 2 \mathrm{H}), 7.61-7.55(\mathrm{~m}, 3 \mathrm{H}), 7.55-7.48(\mathrm{~m}, 3 \mathrm{H}), 7.39(\mathrm{~s}, 1 \mathrm{H})$, $2.50(\mathrm{~s}, 3 \mathrm{H}) .{ }^{13} \mathrm{C}-\mathrm{NMR}\left(100 \mathrm{MHz}\right.$, DMSO- $\left.d_{6}\right) \delta 130.68,130.58,128.74,128.50,126.80,126.02$, 125.65, 21.34; HR-EIMS ${ }^{+}: m / z=308.1311(\mathrm{M})^{+}\left(\right.$Calcd for $\left.\mathrm{C}_{22} \mathrm{H}_{16} \mathrm{~N}_{2}, 308.13\right)$.

\subsection{Synthesis of Probe ABIA}

(1-(2-(Anthracen-9-yl)-5-methyl-1H-benzo[d]imidazol-1-yl)prop-2-en-1-one)

A solution of compound $3(0.1 \mathrm{~g}, 0.32 \mathrm{mmol})$, triethylamine $(0.18 \mathrm{~mL}, 1.29 \mathrm{mmol})$, and DMAP $(0.004 \mathrm{~g}, 0.033 \mathrm{mmol})$ in anhydrous tetrahydrofuran $(25 \mathrm{~mL})$ was stirred at $0{ }^{\circ} \mathrm{C}$ under argon gas for $30 \mathrm{~min}$. Then, prop-2-enoyl chloride $(0.104 \mathrm{~mL}, 1.29 \mathrm{mmol})$ was slowly added to the reaction mixture and continued to be stirred until the completion of the reaction. The reaction progress was monitored by TLC using an ethyl acetate:hexanes (3:7) mixture. After the completion of the reaction $(1 \mathrm{~h}), 100 \mathrm{~mL}$ of $\mathrm{CH}_{2} \mathrm{Cl}_{2}$ was added to the reaction mixture. Then, the reaction mixture was washed three times with the $150 \mathrm{~mL}$ aliquots of saturated $\mathrm{Na}_{2} \mathrm{CO}_{3}$ followed by a single wash of $150 \mathrm{~mL}$ brine. The separated organic layer was then dried over anhydrous $\mathrm{MgSO}_{4}$, and the solvent was evaporated under reduced pressure to obtain the crude product, which was then purified by column chromatography $\left(\mathrm{SiO}_{2}\right.$, ethyl acetate/hexane $\left.=1 / 20, v / v\right)$. The final compound was obtained as a light yellow solid. Yield $82 \mathrm{mg}(74 \%) .{ }^{1} \mathrm{H}-\mathrm{NMR}\left(400 \mathrm{MHz}, \mathrm{DMSO}-d_{6}\right) \delta$ $8.92(\mathrm{~s}, 1 \mathrm{H}), 8.23(\mathrm{~d}, \mathrm{~J}=8.0 \mathrm{~Hz}, 2 \mathrm{H}), 8.13-7.96(\mathrm{~m}, 1 \mathrm{H}), 7.85-7.69(\mathrm{~m}, 1 \mathrm{H}), 7.59(\mathrm{dd}, \mathrm{J}=8.3$, $4.4 \mathrm{~Hz}, 2 \mathrm{H}), 7.54(\mathrm{~d}, \mathrm{~J}=3.2 \mathrm{~Hz}, 4 \mathrm{H}), 7.38(\mathrm{t}, \mathrm{J}=9.8 \mathrm{~Hz}, 1 \mathrm{H}), 5.99(\mathrm{dd}, \mathrm{J}=16.9,3.6 \mathrm{~Hz}, 1 \mathrm{H}), 5.71$ $(\mathrm{ddd}, \mathrm{J}=16.9,10.5,6.5 \mathrm{~Hz}, 1 \mathrm{H}), 5.27(\mathrm{~d}, \mathrm{~J}=10.9 \mathrm{~Hz}, 1 \mathrm{H}), 2.54(\mathrm{~d}, \mathrm{~J}=14.1 \mathrm{~Hz}, 3 \mathrm{H}) .{ }^{13} \mathrm{C}$ NMR $\left(100 \mathrm{MHz}, \mathrm{DMSO}-d_{6}\right) \delta 164.38,164.20,149.45,148.87,143.21,141.05,135.18,134.53,133.39$, $132.52,131.19,130.71$ (A), 130.68 (B), 130.53, 130.01, 128.82, 128.37, 128.25, 127.81, 126.65, 126.25, 125.86, 124.75 (A), 124.62 (B), 119.90 (A), 119.63 (B), 115.16 (A), 114.89 (B), 21.60 (A), 21.08 (B). ((A), (B) represents peak separation due to tautomerization of ABIA, details are shown in Supporting information Figure S7 and Table S1). HR-EIMS ${ }^{+}: m / z=362.1418(\mathrm{M})^{+}$ (Calcd for $\mathrm{C}_{25} \mathrm{H}_{18} \mathrm{~N}_{2} \mathrm{O}, 362.14$ ).

\subsection{UV-Vis and Fluorescence Spectroscopy}

The double-distilled water and spectroscopic grade DMSO were used to prepare the stock and working solutions. The working solution of ABIA $(10 \mu \mathrm{M})$ was prepared by diluting the stock solution of ABIA (1 mM, in DMSO) with a mixture of 90\% DMSO:0.01 M HEPES buffer. The working solutions $(1 \mathrm{mM})$ of amino acids were prepared by diluting the stock solutions $(10 \mathrm{mM}$, in double-distilled) with $0.01 \mathrm{M}$ HEPES buffer. The UV-visible absorption and emission spectra of ABIA $(10 \mu \mathrm{M})$ dissolved in 90\% DMSO:0.01 M HEPES buffer were recorded at room temperature $(298 \mathrm{~K})$ by adding the solution of various analytes such as glycine (Gly), alanine (Ala), serine (Ser), proline (Pro), valine (Val), threonine (Thr), isoleucine (Ile), leucine (Leu), asparagine (Asp), aspartic acid (Asn), glutamine (Gln), lysine (Lys), glutamic acid (Glu), methionine (Met), histidine (His), phenylalanine (Phe), arginine (Arg), tyrosine (Tyr), tryptophan (Typ), homocysteine (Hcy), glutathione (GSH), cysteine (Cys), bovine serum albumin (BSA), and other biologically relevant ions, including $\mathrm{Cl}^{-}$, $\mathrm{Br}^{-}, \mathrm{NO}_{3}{ }^{-}, \mathrm{AcO}^{-}, \mathrm{SO}_{4}{ }^{2-}, \mathrm{PO}_{4}{ }^{3-}, \mathrm{Na}^{+}, \mathrm{Cs}^{+}, \mathrm{Ca}^{2+}$, and $\mathrm{Cu}^{2+}$ to examine the selectivity of ABIA.

For sensitivity study, the titration experiments were accomplished through a stepwise addition of 1.15 equivalents of Cys $(1 \mathrm{mM})$ to a solution of ABIA $(10 \mu \mathrm{M})$. The absorbance intensity and emission intensity were recorded in the range of $200-600 \mathrm{~nm}$ and $350-650 \mathrm{~nm}$, respectively, alongside a reagent blank. The effect of reaction time on the Cys detection was determined by tracing the fluorescence intensity of ABIA $(10 \mu \mathrm{M})$ in the presence of five equivalent Cys $(50 \mu \mathrm{M})$ for 0 to $60 \mathrm{~min}$. The response of ABIA for reaction with Cys obeyed pseudo-first-order kinetics. Therefore, the rate constant was calculated according to the following equation (Equation (1)) [35]: 


$$
\ln \left(\left(F_{\max }-F\right) / F_{\text {max }}\right)=-k t
$$

where $F$ is the fluorescence intensity at time $t, F_{\text {max }}$ is the fluorescence intensity after the reaction, and $k$ is the rate constant. The fluorescence intensity was recorded at $\lambda_{\mathrm{ex}} / \lambda_{\mathrm{em}}=368 / 470 \mathrm{~nm}$ alongside a reagent blank with the excitation and emission slits set to $5.0 \mathrm{~nm}$.

\subsection{Fabrication of CysDDev}

The 3D models of various parts and the main case were created in Autodesk Fusion 360 software. The device's overall size was $130 \times 120 \times 50 \mathrm{~mm}(\mathrm{~W} \times \mathrm{D} \times \mathrm{H})$. CysDDev was assembled with several parts, including the cuvette holder, mounting holes for the LED and sensor, lid for the LED and sensor, the main case, and a top cap lid for the cuvette holder. The cuvette holder could hold a plastic or quartz cuvette with the dimensions of $12.5 \times 12.5 \times 45 \mathrm{~mm}$ dimension. The main body had a hole connecting the device to the computer. When completely assembled and when the top cap lid was mounted, there was no significant light entering the measuring device. Apart from the top cap lid for the cuvette holder, there were no moving components in the device, making it easy to fabricate and assemble. The CysDDev prototype was optimized for fused deposition modeling (FDM) 3D printing. All three parts of the design were printed separately with black thermoplastic filament to lower the reflectivity of the internal surfaces. The electronics parts of the CYSDDev consisted of $9 \mathrm{~V}$ battery, a sensor (Hamamatsu micro-spectrometer C12666MA, Japan) with the detection range $\lambda=340-850 \mathrm{~nm})$, a UV LED (15 mA, $\lambda=370 \mathrm{~nm})$, an Arduino Uno R3 microcontroller for device control and data processing, and a computer connector cable. The LED drew power from a $9 \mathrm{~V}$ battery, and the Arduino microcontroller received the energy from the connected computer. The measured fluorescence profile of a sample by CysDDev was automatically converted into a Microsoft Excel file (.csv) consisting of the information on the wavelength $(\mathrm{nm})$ and respective fluorescence intensity (a.u.).

\section{6. $p H$ Effect on Cys Detection by ABIA}

The effect of $\mathrm{pH}(\mathrm{pH}=3-10)$ on the Cys detection using ABIA was examined by fluorescence spectroscopy. The tetrabutylammonium hydroxide and perchloric acid were used to adjust the $\mathrm{pH}$ of simulated human urine.

\subsection{Detection of Cys Using ABIA and CysDDev in Simulated Human Urine and Real Urine Sample}

Usually, urine $\mathrm{pH}$ is slightly acidic, with typical values of 6.0 to 7.5. However, the range of urine $\mathrm{pH}$ is 4.5 to 8.0. Cys detection using ABIA and CysDDev was performed using simulated urine with a $\mathrm{pH}$ of 6.5. A standard curve was obtained by diluting a stock solution of Cys in analyte-free simulated human urine $(0-150 \mu \mathrm{M})$. Each sample was serially diluted with the analyte-free urine to obtain solutions with concentrations in the detection range. The mean of ten fluorescence signal measurement values (SD in the range of $1.5-9.8 \%$ ) for each calibration point was used to construct the standard curve. The LOD was estimated by applying the IUPAC recommended equation, LOD $=3 \sigma /$ slope [36]. Where $\sigma$ is the standard deviation of $(n=10)$ blank samples and the slope for the calibration curves.

A real urine sample obtained from a healthy volunteer was used for the spiking test and to validate the applicability of the ABIA and CysDDev in clinical samples. An amount of $5 \mu \mathrm{L}$ urine from a healthy volunteer spiked with various $C y$ s concentrations was added to the ABIA solution, and the fluorescence intensities were measured. Then, the percent recovery was measured using the standard curve.

\subsection{Cell Culture, Cytotoxicity Assay, and Bio-Imaging}

The cytotoxicity assay (MTT (3-(4,5-dimethylthiazol-2-yl)-2,5-diphenyltetrazolium bromide) assay) of ABIA, Cys, and Cys combined with the probe ABIA was performed using A549 cells (adenocarcinomic human alveolar basal epithelial cells), as reported earlier [37,38]. In brief, about 7000 A549 cells per well were seeded in 96-well plates and 
were allowed to incubate for $24 \mathrm{~h}$. Then, the solution in the wells was replaced by media containing ABIA, Cys, and ABIA with Cys (1, 10, 25, and $50 \mu \mathrm{M})$ and was incubated for another $24 \mathrm{~h}$. The dimethyl sulfoxide (DMSO) was used as a control. About $200 \mu \mathrm{L}$ of a media containing MTT solution was added to each well and was allowed to incubate for four hours at $37^{\circ} \mathrm{C}$. Finally, the absorbance was recorded at $570 \mathrm{~nm}$ to determine the cell cytotoxicity. The experiment was repeated three times, and the results were presented with mean and standard deviation.

The bio-imaging experiments were performed by seeding the A549 cells on glassbottom culture dishes and incubating them for $48 \mathrm{~h}$. For control experiments, cells were only treated with the culture medium and were observed under the confocal microscope after being washed three times with $0.1 \mathrm{M}$ PBS $(0.5 \mathrm{~mL})$. For treatment, cells were treated with $500 \mu \mathrm{M}$ of Cys and $25 \mu \mathrm{M}$ of ABIA separately and were allowed to incubate for $1 \mathrm{~h}$ at $37{ }^{\circ} \mathrm{C}$ and $5 \% \mathrm{CO}_{2}$ and were then washed three times with $0.1 \mathrm{M}$ PBS $(0.5 \mathrm{~mL})$ before observation. For the bio-imaging of Cys by ABIA, cells were incubated with $500 \mu \mathrm{M}$ of Cys for $1 \mathrm{~h}$ followed by replacing the media containing $25 \mu \mathrm{M}$ of ABIA and incubating the cells for another $1 \mathrm{~h}$. Then, the cells were washed three times with $0.1 \mathrm{M}$ PBS $(0.5 \mathrm{~mL})$ before observation. For another control experiment, cells were treated with $1 \mathrm{mM}$ N-ethylmaleimide (NEM, a biothiol scavenger) for $30 \mathrm{~min}$ at $37^{\circ} \mathrm{C}$ followed by washing three times with $0.1 \mathrm{M}$ PBS $(0.5 \mathrm{~mL})$. Then, the cells were incubated in the presence of $25 \mu \mathrm{M}$ of ABIA for $1 \mathrm{~h}$ followed being washed three times with $0.1 \mathrm{M}$ PBS $(0.5 \mathrm{~mL})$ before observation. In a similar experiment, cells pre-tread with NEM (1 mM), as mentioned above, were treated with Cys (500 $\mu \mathrm{M}$, for $1 \mathrm{~h})$ followed being washed with $0.1 \mathrm{M}$ PBS $(0.5 \mathrm{~mL} \times 3)$ and then incubated in the presence of ABIA $(25 \mu \mathrm{M}, 1 \mathrm{~h})$ and finally being washed three times $0.1 \mathrm{M}$ PBS $(0.5 \mathrm{~mL})$ before observation. Finally, the PBS $(1 \mathrm{~mL})$ was added to each glass-bottom culture dish, and then the fluorescence images were recorded using a confocal microscope (Carl Zeiss LSM710).

\section{Results}

\subsection{Synthesis and Characterization of the Probe ABIA}

The probe ABIA was synthesized in a two-step reaction as depicted in Scheme 1.

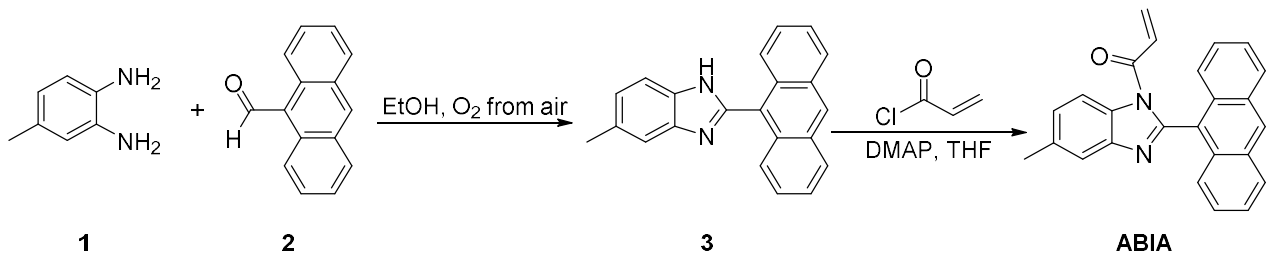

Scheme 1. Scheme for the synthesis of the probe ABIA.

In the first step, a simple yet efficient method for the synthesis of compound 3 was developed. The reaction of 4-methylbenzene-1,2-diamine $(4.0 \mathrm{mmol})$ and anthracene-9carbaldehyde $(4.0 \mathrm{mmol})$ in ethanol at room temperature in the presence of $\mathrm{O}_{2}$ from the air and visible light allowed us to afford compound 3 with $80 \%$ yield (see the Supplemental Information Figures S1-S3). To the best of our knowledge, this is a first report on the synthesis of compound 3 . The reported synthetic procedures to obtain benzimidazole derivatives are different than the one employed here $[39,40]$. The previously reported methods used stringent reaction conditions, including dimethyl sulfoxide as a solvent, the temperature of $110^{\circ} \mathrm{C}$, and $\mathrm{I}_{2}$ as a catalyst. It is important to note that the procedure employed here uses mild reaction conditions, including ethanol as a solvent and $25{ }^{\circ} \mathrm{C}$ without using the additional catalyst. The method presented here allowed the synthesis of compound 3 with comparable yield.

In a second step, compound 3 was reacted with the prop-2-enoyl chloride $(1.29 \mathrm{mmol})$ in the presence of triethylamine $(1.29 \mathrm{mmol})$ and DMAP $(0.033 \mathrm{mmol})$ to afford the final compound ABIA (see the Supplemental Information Figures S4-S6) in comparable yield. 
The ${ }^{1} \mathrm{H}$ NMR and ${ }^{13} \mathrm{C}$ NMR spectra of ABIA demonstrate the 5(6)-methyl tautomerism related to the $\mathrm{N}$-substituted benzimidazoles (see the Supplemental Information Figure S7 and Table S1). According to previous reports, the tautomerism in benzimidazole derivatives is a well-known phenomenon, and in most cases, the separation of tautomers by column chromatography is not feasible [41,42]. Hence, we used the tautomeric mixture of ABIA in further experiments. The photophysical properties of compound $3(10 \mu \mathrm{M})$ and probe ABIA $(10 \mu \mathrm{M})$ in 90\% DMSO:0.01 M HEPES buffer solution did not indicate a significant effect of tautomerism in ABIA. As shown in Figure 1, the optical absorbance spectrum of compound 3 shows $\lambda_{\text {ex }}$ at $368 \mathrm{~nm}$ and another two peaks at $353 \mathrm{~nm}$ and $388 \mathrm{~nm}$. The emission spectra of compound 3 show $\lambda_{\text {em }}$ at $475 \mathrm{~nm}\left(\lambda_{\mathrm{ex}}=368 \mathrm{~nm}\right)$, indicating Stoke's shift of $107 \mathrm{~nm}$. Similarly, the probe ABIA demonstrates three distinct peaks (356, 372, and $392 \mathrm{~nm}$ ) with the absorption maxima at $372 \mathrm{~nm}$.

(a)

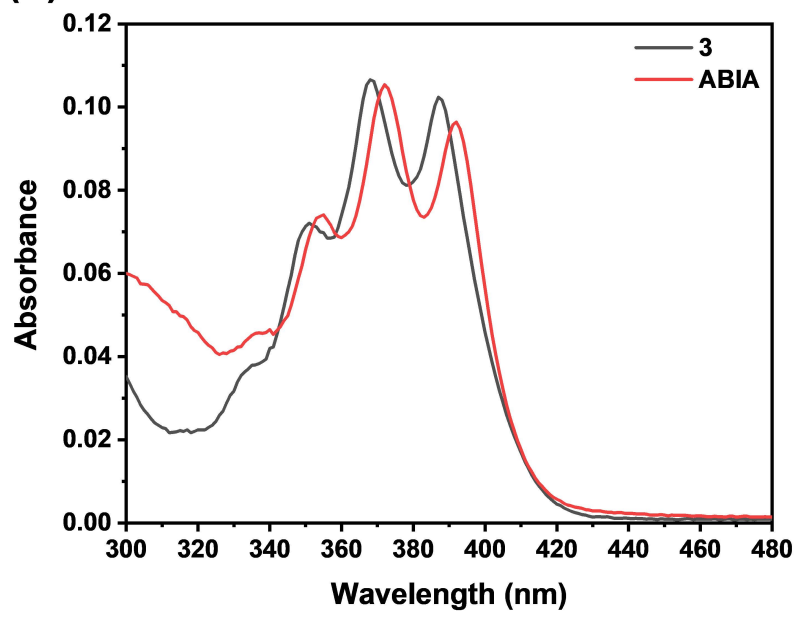

(b)

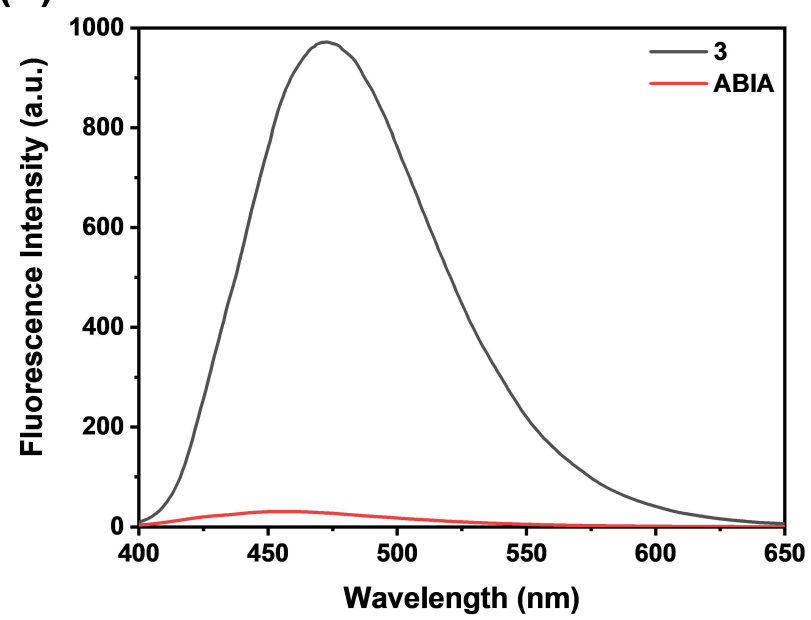

Figure 1. (a) UV-vis and (b) fluorescence emission spectra of compound $3\left(10 \mu \mathrm{M} ; \lambda_{\mathrm{ex}}=368 \mathrm{~nm}\right)$ and the probe ABIA $(10 \mu \mathrm{M})$ in 90\% DMSO:0.01 M HEPES buffer solution $\left(\lambda_{\mathrm{ex}}=372 \mathrm{~nm}\right)$.

Interestingly, ABIA showed fluorescence $\left(\lambda_{\mathrm{em}}=453 \mathrm{~nm}\right)$ that was almost 30-fold lower than compound 3, indicating that the intramolecular charge transfer induced fluorescence quenching due to the N1-substituted acrylate group. The acrylate group has a strong electron-withdrawing ability that enhances the fluorescence turn-off effect in ABIA. These results indicate that reaction-induced removal of the acrylate group in ABIA can result in compound 3 with the fluorescence turn-on effect. Hence, the spectral characteristics of compound 3 were studied using various ratios $(10,50,70$, and $90 \%$ ) of the DMSO:0.01 M HEPES buffer solution. As shown in Figure S8 and Table S2, compound 3 shows aggregation-induced fluorescence quenching with the increasing water percentage. It is important to note that 10\% DMSO DMSO:0.01 M HEPES buffer solution completely dissolved $10 \mu \mathrm{M}$ of compound $\mathbf{3}$. However, compound $\mathbf{3}$ showed maximum fluorescence in 90\% DMSO:0.01 M HEPES buffer solution. Hence, other fluorimetric experiments were conducted in 90\% DMSO: 0.01 M HEPES buffer solution $\left(\lambda_{\mathrm{ex}}=368 \mathrm{~nm}\right)$.

\subsection{Determination of Selectivity of the Probe ABIA as a Chemosensor for Cys}

The selectivity of the probe ABIA for Cys detection was investigated using fluorescence spectroscopy. The fluorescence spectra of ABIA (10 $\mu \mathrm{M}$, in 90\% DMSO:0.01 M HEPES buffer solution) were recorded immediately $(1 \mathrm{~min})$ after adding the five equivalents of various amino acids, $\mathrm{BSA}$, anions $\left(\mathrm{Cl}^{-}, \mathrm{Br}^{-}, \mathrm{NO}_{3}{ }^{-}, \mathrm{AcO}^{-}, \mathrm{SO}_{4}{ }^{2-}, \mathrm{PO}_{4}{ }^{3-}\right)$, and cations $\left(\mathrm{Na}^{+}, \mathrm{Cs}^{+}, \mathrm{Ca}^{2+}, \mathrm{Cu}^{2+}\right)$ to the solution containing ABIA. As shown in Figure 2a, ABIA showed negligible fluorescence. However, the fluorescence intensity of ABIA increased significantly in the presence of Cys $\left(\lambda_{\mathrm{em}}=455 \mathrm{~nm}\right)$ compared to the other analytes. Among the mercapto group-containing amino acids, ABIA showed 6-fold and 15-fold higher se- 
lectivity for Hcy $\left(\lambda_{\mathrm{em}}=460 \mathrm{~nm}\right)$ and GSH $\left(\lambda_{\mathrm{em}}=475 \mathrm{~nm}\right)$, respectively. In contrast, the selectivity for Cys was 50-fold higher than other amino acids. Further, ABIA did not show any interaction with biologically relevant ions such as $\mathrm{Cl}^{-}, \mathrm{Br}^{-}, \mathrm{NO}_{3}^{-}, \mathrm{AcO}^{-}, \mathrm{SO}_{4}{ }^{2-}$, $\mathrm{PO}_{4}{ }^{3-}, \mathrm{Na}^{+}, \mathrm{Cs}^{+}, \mathrm{Ca}^{2+}$, and $\mathrm{Cu}^{2+}$. As shown in Figure $2 \mathrm{~b}$, in competition experiments conducted in the presence of an excess of (five equivalents) other amino acids, including Hcy and GSH, ABIA did not show any interference in the detecting Cys. However, among the tested biologically relevant ions, only $\mathrm{Cu}^{2+}$ affected the detection of Cys at tested equimolar concentrations $(50 \mu \mathrm{M})$. Cys forms a coordination complex with $\mathrm{Cu}^{2+}$ ions using the mercapto and carboxylate functional groups [43]. Therefore, the complexation of Cys with $\mathrm{Cu}^{2+}$ inhibits its nucleophilic addition ability to the acrylate group of ABIA. However, the amount of $\mathrm{Cu}^{2+}(180 \mathrm{nM})$ [44] is negligible compared to Cys in healthy human urine $(120 \mu \mathrm{M})$ and in the urine of cystinuria patients $(2000 \mu \mathrm{M})[45,46]$. Thus, $\mathrm{Cu}^{2+}$ would not interfere in Cys detection using the probe ABIA in the actual urine sample. These results indicate that ABIA is a highly selective fluorescence turn-on probe for Cys, and it can be applied to detect intracellular and urinary Cys.

(a)

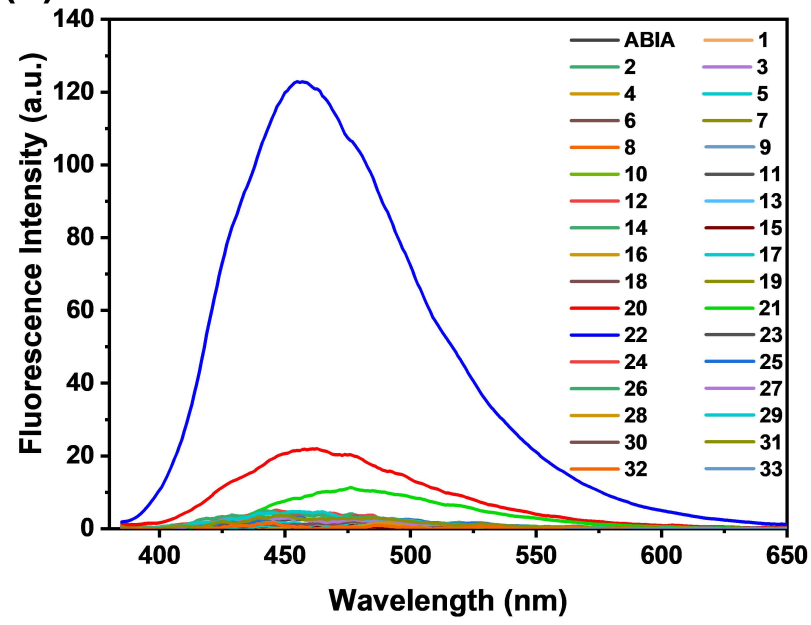

(b)

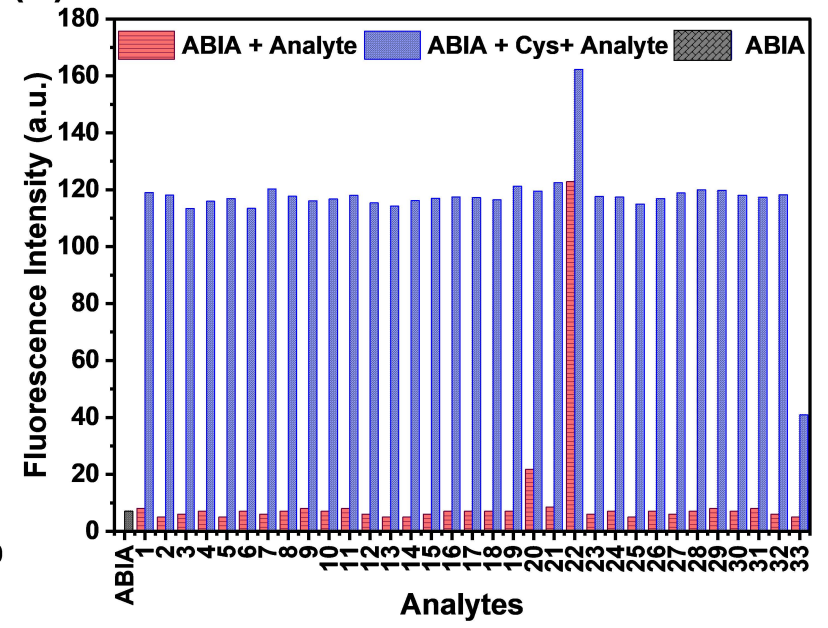

Figure 2. (a) Fluorescence spectra and (b) competitive study of ABIA $\left(10 \mu \mathrm{M}, \lambda_{\mathrm{ex}}=368 \mathrm{~nm}, \lambda_{\mathrm{em}}=455 \mathrm{~nm}\right)$ in the absence and presence of five equivalents of various analytes (50 $\mu \mathrm{M})$. 1, Gly; 2, Ala; 3, Ser; 4, Pro; 5, Val; 6, Thr; 7, Ile; 8, Leu; 9, Asn; 10, Asp; 11, Gln; 12, Lys; 13, Glu; 14, Met; 15, His; 16, Phe; 17, Arg; 18, Tyr; 19, Typ; 20, Hcy; 21, Gsh; 22, Cys; 23, BSA; 24, $\mathrm{Cl}^{-} ; 25, \mathrm{Br}^{-} ; 26, \mathrm{NO}_{3}{ }^{-} ; 27, \mathrm{AcO}^{-} ; 28, \mathrm{SO}_{4}{ }^{2-} ; 29, \mathrm{PO}_{4}{ }^{3-} ; 30, \mathrm{Na}^{+} ; 31, \mathrm{Cs}^{+} ; 32, \mathrm{Ca}^{2+} ; 33, \mathrm{Cu}^{2+}$.

To estimate the minimum response time, we traced the time-dependent fluorescence intensity of ABIA $(10 \mu \mathrm{M})$ for 60 min upon the addition of five equivalents of Cys, as shown in Figure S9. The fluorescence intensity almost reached the maximum (310 a.u.) in 10 min after the addition of Cys. It is important to note that the fluorescence intensity was 121 a.u. within 1 min after adding Cys, which was comparatively fast compared to the reported probes, considering the structural simplicity of ABIA (see the Supplemental Information Table S3). In addition, we calculated the pseudo-first-order rate constants of the reactions between ABIA $(10 \mu \mathrm{M})$ and five equivalents of Cys. The calculated pseudo-first-order rate constants for Cys from the linear regression analysis of time-dependent changes in the fluorescence intensity was $5.13 \times 10^{-3} \mathrm{~s}^{-1}$, as shown in Figure S9. These results indicate that the ABIA shows high specificity for Cys and a short reaction time (1 min). Hence, ABIA is applicable for the detection and quantification of Cys in urine and live cells.

The Cys detection mechanism by ABIA was studied using ${ }^{1} \mathrm{H}$ NMR spectroscopy and mass spectroscopy. As shown in Figure 3, 0.5 and 1.0 equivalents of Cys were added to the 90\% DMSO:0.01 M HEPES buffer solution (DMSO- $d_{6}$ and $\mathrm{D}_{2} \mathrm{O}$ were used to make this solution) containing ABIA. Upon reaction, the peaks at 5.26, 5.71, and 5.97 ppm corresponding to the acrylate group of ABIA completely disappeared with 1.0 equivalents of Cys. These results indicate that the mercapto group in Cys undergoes the Michael 
addition with the double bond in the acrylate group of ABIA. Further, the appearance of new peaks at 2.26, 2.34, and $3.05 \mathrm{ppm}$ indicates the intramolecular attack of the amine group of Cys on the carbonyl of ABIA, resulting in the cyclized product along with compound 3, as shown in Figure $3 \mathrm{~b}$. The formation of compound $\mathbf{3}$ after the reaction of ABIA with Cys indicates the resultant fluorescence "turn-on" mechanism. Further proof for the proposed mechanism presented in Figure $3 \mathrm{~b}$ was deduced from the mass spectra of a reaction product obtained by reacting equimolar ABIA and CYS for $60 \mathrm{~min}$ at $25^{\circ} \mathrm{C}$ in $90 \%$ DMSO:0.01 M HEPES buffer solution. The solvent was evaporated at $40{ }^{\circ} \mathrm{C}$ under high-vacuum, and the resultant residue was prepared for the acquisition of the mass spectra by dissolving it in methanol. As presented in Figure $3 \mathrm{~b}$ and Figure S10, the cyclization process of Cys after the reaction with ABIA generates a seven-membered ring $\left(\right.$ calcd. $\left(\mathrm{H}^{+}\right)$: 176.0376; found $m / z:$ 176.0) and compound 3 (calcd. $\left(\mathrm{H}^{+}\right)$: 308.368; found $m / z$ : 308.0) upon the de-acrylation of ABIA. Therefore, these results indicate the high applicability of ABIA as a fluorescence turn-on sensor for Cys in live cells and urine samples.

(a)

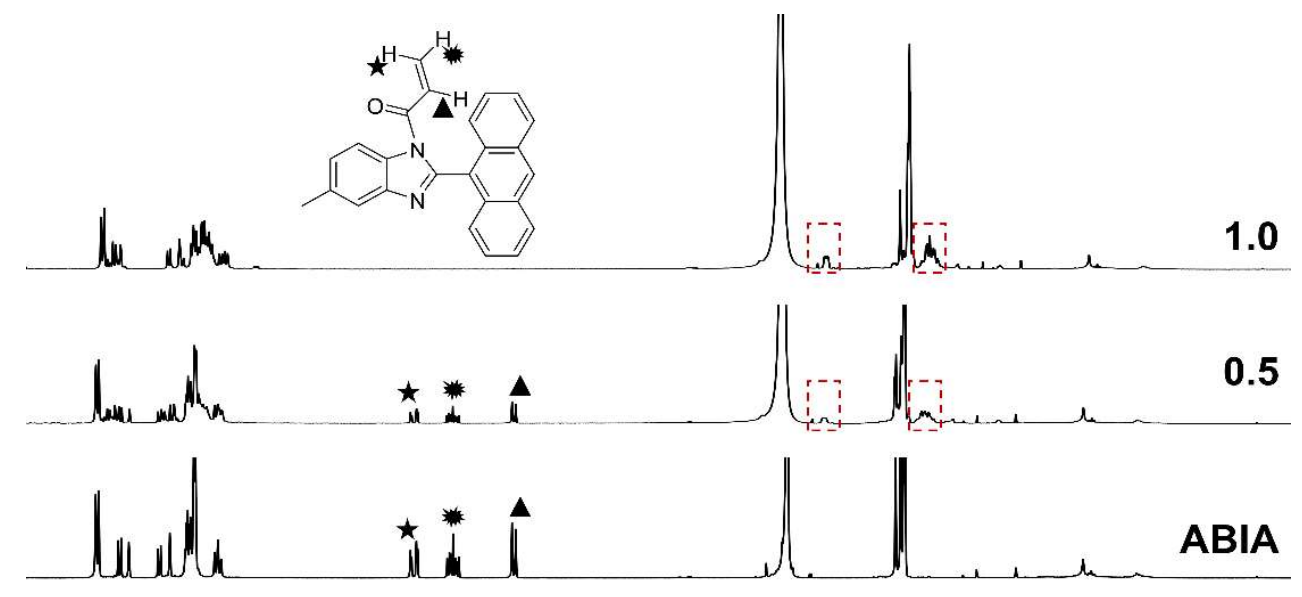

8.58 .07 .57 .06 .56 .05 .55 .04 .54 .03 .53 .02 .52 .01 .51 .00 .50 .0

(b)

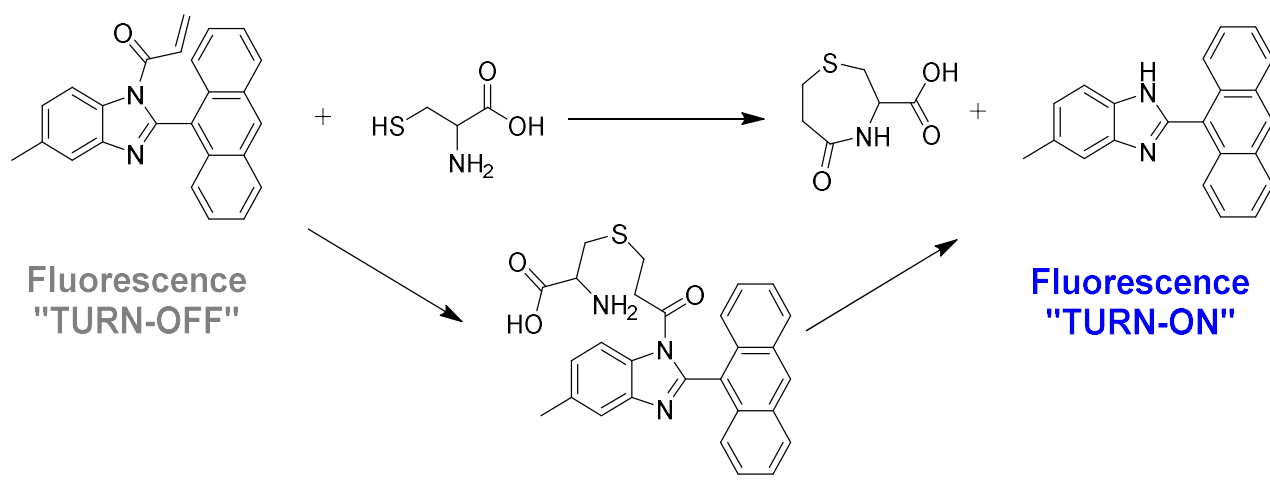

Figure 3. (a) Changes in ${ }^{1} \mathrm{H}$ NMR spectra of ABIA upon the addition of 0.5 and 1.0 equivalents of Cys in $90 \%$ DMSO- $d_{6}: 0.01$ M HEPES buffer solution $\left(\mathrm{D}_{2} \mathrm{O}\right) ;(\mathbf{b})$ proposed Cys detection mechanism by ABIA.

\subsection{The Design and Application of CysDDev for Detecting Cys in Simulated Human Urine}

A schematic of the CysDDev prototype is shown in Figure 4. The LED was arranged in a nozzle opening at a $90^{\circ}$ angle to the sensor nozzle in the cuvette holder, allowing efficient sample illumination by UV LED and detecting emitted light by the sensor. An electric current of $15 \mathrm{~mA}$ was delivered to the UV LED $(\lambda=370 \mathrm{~nm})$ under a bias of $9 \mathrm{~V}$ 
using a rechargeable Li-ion battery. The analog signals from the sensor consisted of a train of pulses correlating to the spatial position of 256 pixels corresponding to wavelengths in the range of 340-850 $\mathrm{nm}$. The analog data collected from the analog pin of the sensor were digitized in a bit resolution of 10 bits using the Arduino Uno R3 microcontroller that sends the processed data to the computer. The final data of individual sample readings were saved as a Microsoft Excel file (.csv) in the pre-selected folder on the connected computer.

(a)

(b)
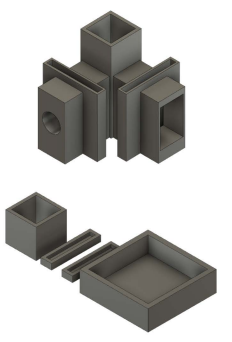

(c)

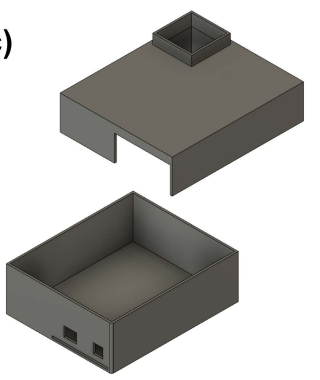

(d)

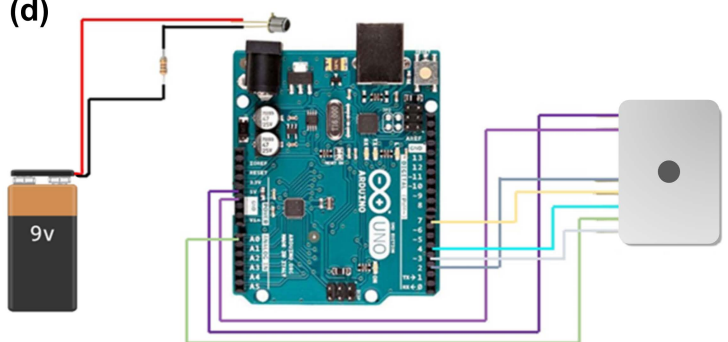

(e)

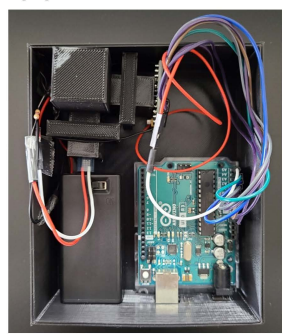

(f)

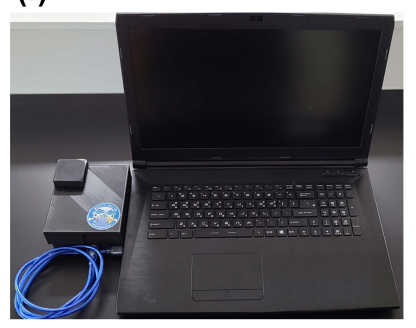

Figure 4. Schematic of various parts of the CysDDev (a): UV LED, sensor, and cuvette holder; (b) top lids for UV LED, sensor, cuvette holder; (c) the main case with top lid; (d) electronic components connected to the Arduino microcontroller; (e) assembly of CysDDev without the top lid; (f) CysDDev prototype connected to the laptop computer.

We compared the performance of CysDDev with the commercial fluorescence spectrometer using the ABIA $(10 \mu \mathrm{M})$ and compound $3(10 \mu \mathrm{M})$ in 90\% DMSO:0.01 M HEPES buffer solution. As shown in Figure 5a, the CysDDev showed comparable results with the commercial fluorescence spectrometer for compound $\mathbf{3}$ and the probe ABIA. These results indicate that the CysDDev developed here can detect $C y s$ in various solutions, including in urine.

(a)

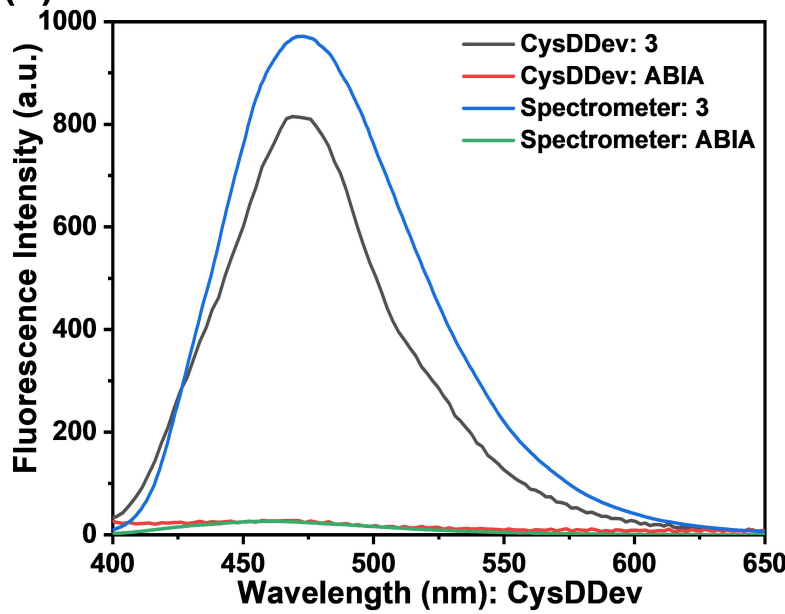

(b)

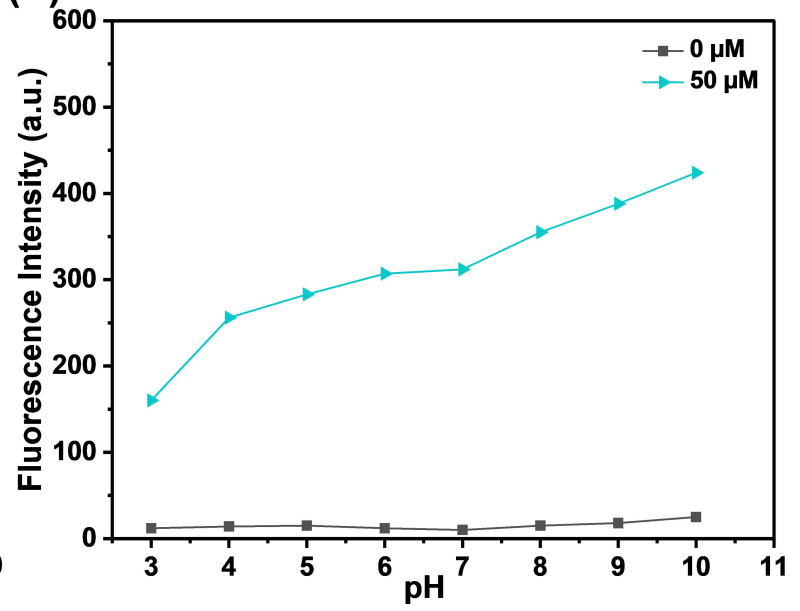

Figure 5. (a) Fluorescence spectra of compound $3\left(10 \mu \mathrm{M}, \lambda_{\mathrm{ex}}=370 \mathrm{~nm}\right)$ and ABIA $\left(10 \mu \mathrm{M}, \lambda_{\mathrm{ex}}=370 \mathrm{~nm}\right)$ recorded using CysDDev and commercial fluorescence spectrometer; (b) effect of $\mathrm{pH}$ on the detection of Cys $(0,50 \mu \mathrm{M})$ in simulated human urine at various $\mathrm{pH}$ using ABIA and CysDDev $\left(\lambda_{\mathrm{ex}}=370 \mathrm{~nm}, \lambda_{\mathrm{em}}=455 \mathrm{~nm}\right)$. 


\subsection{Effect of $\mathrm{pH}$ on the Detection of Cys by ABIA}

The effect of $\mathrm{pH}(\mathrm{pH}=3-10)$ on the detection of Cys using ABIA was examined by using CysDDev both in the absence and presence of Cys $(50 \mu \mathrm{M})$ in simulated human urine, as shown in Figure 5b. The fluorescence intensity of the probe ABIA in the absence of Cys did not show a significant change in the studied $\mathrm{pH}$ range of 3-10, indicating that the ABIA has remarkable stability in acidic and alkaline environments. The fluorescence intensity increased in the presence of various concentrations of $\mathrm{Cys}$ from $\mathrm{pH} 3.0-10.0$. The $p K a$ values of the Cys for $\alpha-\mathrm{NH}_{3}{ }^{+}(p K a=10.25)$ and $-\mathrm{SH}(p K a=8.0)$ groups dictate that below $\mathrm{pH} 8$, the $-\mathrm{SH}$ is the only nucleophile reacting with the acrylate group of ABIA. However, over $\mathrm{pH} 8$, the nucleophilicity of $\mathrm{Cys} \alpha-\mathrm{NH}_{2}$ increases. Hence, over $\mathrm{pH} 8$, the $-\mathrm{SH}$ and $-\mathrm{NH}_{2}$ groups of $\mathrm{Cys}$ can react with $\mathrm{ABIA}$ and can enhance the de-acrylation process, resulting in higher fluorescence intensity with increasing $\mathrm{pH}$. Unlike reported probes for Cys detection that require use at $\mathrm{pH} \geq 9.0$ [47-49], ABIA can detect $\mathrm{Cys}$ in the physiological $\mathrm{pH}$ range and the typical urine $\mathrm{pH}$ values of 6.0 to 7.5 .

\subsection{Detection of Cys Using ABIA and CysDDev in Simulated Human Urine and Real Urine Sample}

Cys detection using ABIA and CysDDev was performed using urine with a $\mathrm{pH}$ of 7.4. As shown in Figure 6, a calibration plot $(0-150 \mu \mathrm{M})$ was obtained by diluting a stock solution of Cys.

(a)

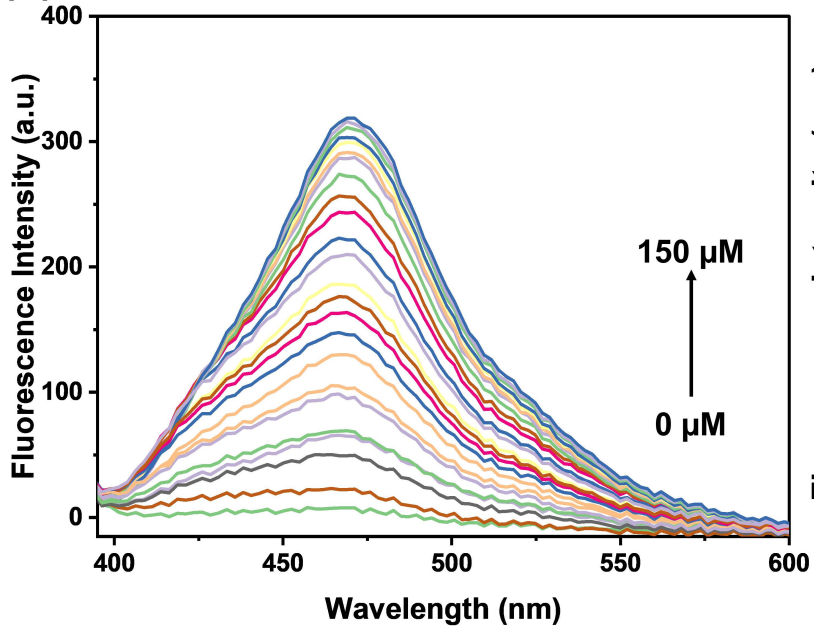

(b)

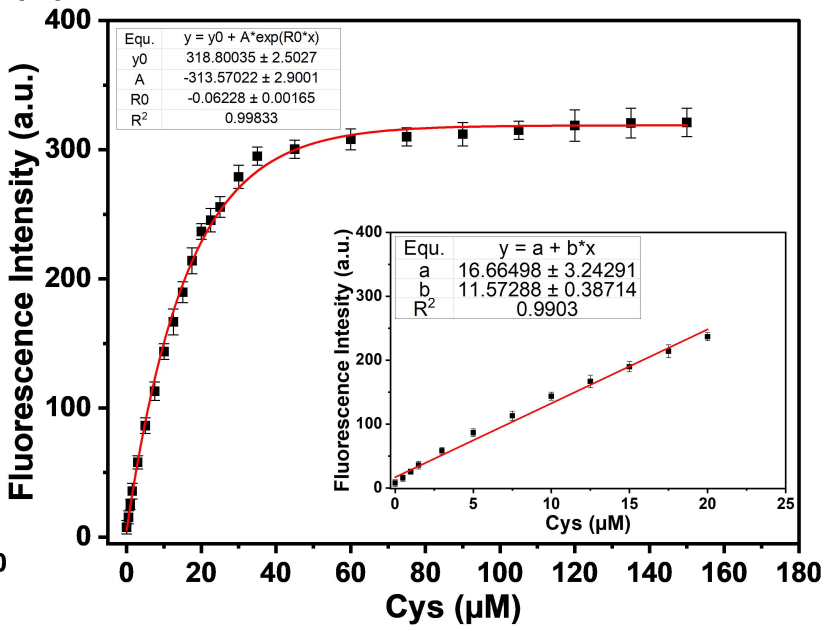

Figure 6. (a) Changes in fluorescence spectra of ABIA $\left(10 \mu \mathrm{M}, \lambda_{\mathrm{ex}}=370 \mathrm{~nm}\right)$ recorded using CysDDev upon the successive addition Cys $(0-150 \mu \mathrm{M})$ in urine at $\mathrm{pH}=7.3(\mathbf{b})$ Calibration curves for the detection of Cys in urine using ABIA and CysDDev $\left(\lambda_{\mathrm{ex}}=370 \mathrm{~nm}, \lambda_{\mathrm{em}}=455 \mathrm{~nm}\right)$ Inset is the linear regression curve in the range of $0-20 \mu \mathrm{M}$ of Cys.

As depicted in Figure 6, the fluorescence signals of ABIA $(10 \mu \mathrm{M})$ increase linearly upon the successive addition of Cys until $20 \mu \mathrm{M}$ and then reach the plateau around $50 \mu \mathrm{M}$ and remains the same until $150 \mu \mathrm{M}$. The LOD for detecting Cys by ABIA using CysDDev was found to be $16.3 \mathrm{nM}$, with a linear detection range of $0-20 \mu \mathrm{M}$. It is imperative to note that ABIA demonstrated relatively lower detection limits for Cys than the other methods presented in Table S4.

Here, we used the standard addition method to quantify the Cys in the urine sample of a healthy volunteer to minimize the interference from the urine components. The fresh urine sample without any pretreatment was spiked with 3,6, and $9 \mu \mathrm{M}$ of Cys, and the spiked recovery was measured using the standard curve (Figure $6 \mathrm{~b}$ (inset)). The results of the spike test are presented in Table 1. As shown in Table 1, the probe ABIA and CysDDev can effectively detect the Cys in the real urine sample with statistically significant recovery $(99.20-104.9 \%)$ and precision (RSD $<1.45 \%)$. 
Table 1. Spike recovery test using real urine sample from a healthy volunteer.

\begin{tabular}{cccc}
\hline Spiked Cys & Found Cys & Recovery & RSD $(n=3)$ \\
\hline$(\boldsymbol{\mu M})$ & $(\boldsymbol{\mu M})$ & $\mathbf{( \% )}$ & $\mathbf{( \% )}$ \\
\hline 3 & 3.14 & 104.9 & 1.45 \\
6 & 5.95 & 99.2 & 1.22 \\
9 & 9.77 & 108.6 & 0.50 \\
\hline
\end{tabular}

RSD, relative standard deviation.

\subsection{Cell Imaging Application of ABIA for the Detection of Cys}

The MTT assay allowed us to estimate cytotoxicity by treating cells with $0.1,10,25$, and $50 \mu \mathrm{M}$ of ABIA, Cys, and ABIA + Cys for $24 \mathrm{~h}$ using DMSO as a control. The cytotoxicity assay results are depicted in Figure $7 \mathrm{a}$ as the percent cell growth after treatment with ABIA, Cys, and ABIA + Cys compared to the control. There was no significant cell death even after $24 \mathrm{~h}$ of treatment at all tested concentrations. Therefore, $25 \mu \mathrm{M}$ of ABIA was used for the cell imaging applications. As shown in Figure $7 \mathrm{~b}$, the control cells, cells treated Cys $(500 \mu \mathrm{M})$, and cells pretreated with NEM $(1 \mathrm{mM})$ followed by treatment with ABIA $(25 \mu \mathrm{M})$ did not show significant fluorescence. However, the fluorescence intensity was observed upon the treatment of cells with Cys $(500 \mu \mathrm{M})$ followed by ABIA $(25 \mu \mathrm{M})$. Further, the fluorescence intensities were also observed in the cells pretreated with NEM $(1 \mathrm{mM})$ followed sequentially by the treatment of Cys $(500 \mu \mathrm{M})$ and ABIA $(25 \mu \mathrm{M})$. These results indicate that the fluorescence turn-on probe ABIA has high potential in biological applications detecting intracellular Cys in the in vitro assays.

(a)

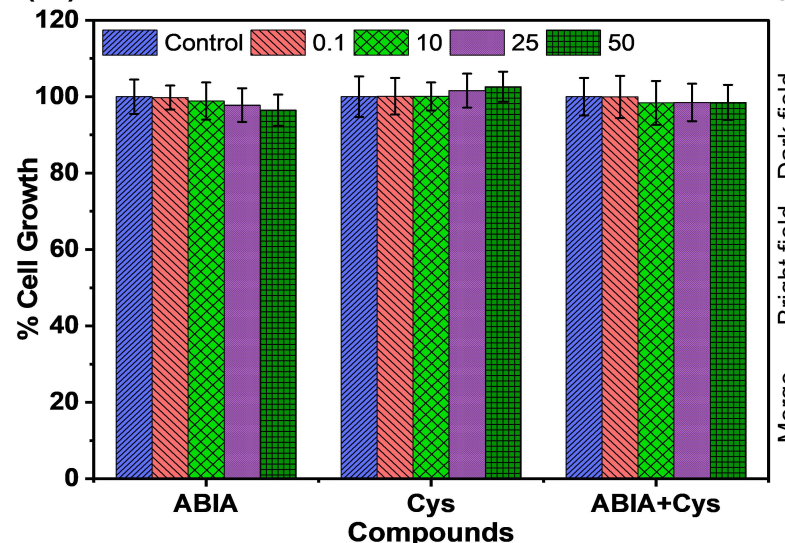

(b)

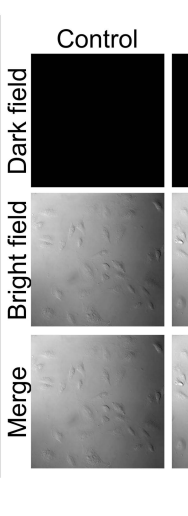

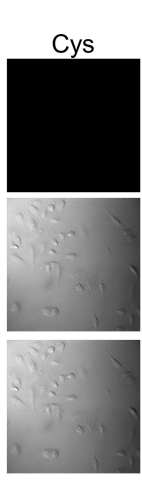

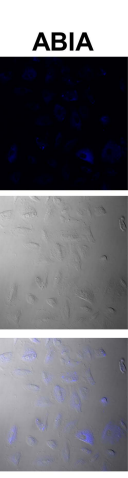

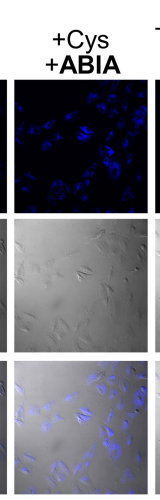

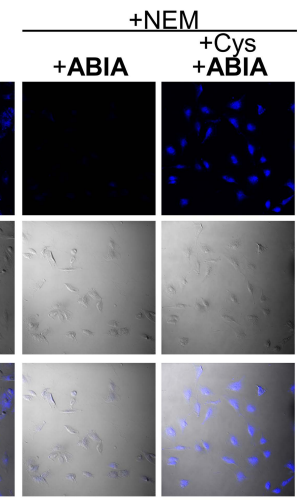

Figure 7. (a) Cytotoxicity's of ABIA, Cys, and ABIA + Cys on A549 cells at concentrations of 0.1, 10, 25, and 50 $\mu \mathrm{M}$ after 24 h; (b) Dark field, bright field, and merged images upon treatment of A549 cells with control, Cys, ABIA, Cys + ABIA, $\mathrm{NEM}+$ ABIA, and NEM + Cys + ABIA.

\section{Discussion}

There are several reports on the methods that are developed for detecting biothiols. Fluorescence turn-on sensors have attracted attention because of their high sensitivity, ease of operation, and fluorescence imaging in living cells. The Michael addition reaction [50], cyclization with aldehydes [51], conjugate addition-cyclization reaction [52], cleavage of sulfonamide, sulfonate esters [53], etc., reaction mechanisms have been reported for Cys detection among these sensors.

Most of the reported Cys detection probes are based on the coumarin scaffold with larger and more complicated structures [54,55]. Therefore, developing a synthetically accessible fluorescent probe with a simple design that shows high sensitivity and selectivity for detecting Cys can demonstrate several applications. Among the various fluorescent probes used for detecting biothiols, acrylate groups provide a fast response to the mercapto group 
and have a higher ability to quench fluorescence due to their strong electron-withdrawing effect $[43,56,57]$. Further, there are a few benzimidazole derivatives, such as fluorescent chemosensors [58,59]. However, in most cases, the benzimidazole moiety demonstrates fluorescence in the UV region $\left(\lambda_{\mathrm{em}}<400 \mathrm{~nm}\right)$ [60], which is not suitable for live-cell imaging applications. The probe ABIA presented here contains an anthracene moiety, due to which it demonstrates fluorescence in the visible region, unlike other reported benzimidazole derivatives.

Compound 3, which was presented in this manuscript, exhibited high fluorescence, upon which the subsequent reaction with acryloyl chloride resulted in the non-fluorescent ABIA. The directly linked acrylate group to the benzimidazole skeleton triggered an intramolecular charge transfer (ICT), resulting in a fluorescence turn-off effect. However, the Michael addition of the Cys mercapto group to the acrylate of ABIA restricted the ICT process and results in a fluorescence turn-on effect. ABIA shows selectivity for Cys over Hcy, probably because the rection of ABIA with Cys generates a seven-membered ring. In comparison, a reaction of ABIA with Hcy would produce an eight-membered ring. The strain in an eight-membered ring is much higher than that in a seven-membered ring; thus, a favorable seven-membered ring product forms easily. ABIA demonstrated high selectivity and comparatively fast response time for Cys detection (see the Supporting Information Table S3). The live-cell imaging study presented here provides evidence that ABIA has high applicability for in vitro bioimaging for Cys.

Reported probes were used for either the bioimaging or detection of Cys in serum samples. Only a few reports elaborate upon Cys detection in urine. However, the probe ABIA presented here was evaluated for its dual application for detecting Cys in live cells and urine. The CysDDev explained here allows the efficient detection of Cys in simulated human urine. The LOD for Cys detection by the probe ABIA using CysDDev was found to be of $16.3 \mathrm{nM}$. The CysDDev and ABIA demonstrated excellent clinical applicability in terms of LOD for Cys detection compared to reported methods (see the Supporting Information Table S4). Though the further evaluation of CysDDev for clinical application is required, these initial results indicate that CysDDev is an excellent portable tool that is deployable in resource-limited settings. The portability and the ease of use make CysDDev a perfect point-of-care device for evaluating clinical samples.

\section{Conclusions}

The novel fluorescence "off-on" probe ABIA to detect the mercapto-group containing amino acids was designed and synthesized. In addition, a portable device, CysDDev, was also designed and developed to measure the Cys in urine. The probe ABIA and CysDDev exhibited highly sensitive, simple, rapid, and inexpensive cysteine detection ability. The acrylate group in ABIA reacted with the mercapto group in Cys by means of the Michael addition reaction mechanism. The Michael addition reaction was followed by selective intramolecular nucleophilic substitution, ensuring selective detection of Cys over Hcy and GSH. The response time of $1 \mathrm{~min}$ and a detection limit of $16.3 \mathrm{nM}$ signifies the high clinical applicability of ABIA and CysDDev. Further, ABIA also demonstrated its utility in detecting intracellular cysteine, making it an excellent probe for bio-imaging assay.

These results suggest that the ABIA and CysDDev will provide new insights into developing convenient approaches in Cys and other biomarker detections through simple, accurate, and portable health products for potential biological applications.

Supplementary Materials: The following are available online at https:/ /www.mdpi.com/article/10 .3390 / bios11110420/s1, Figure S1: ${ }^{1} \mathrm{H}-\mathrm{NMR}$ spectrum of compound 3, Figure S2: ${ }^{13} \mathrm{C}-\mathrm{NMR}$ spectrum of compound 3, Figure S3: HR-mass spectrum of compound 3, Figure S4: ${ }^{1} \mathrm{H}-\mathrm{NMR}$ spectrum of ABIA, Figure S5: ${ }^{13}$ C-NMR spectrum of ABIA, Figure S6: HR-mass spectrum of ABIA, Figure S7: Structures of the probe ABIA tautomer's A and B, Figure S8: (a) UV-vis absorbance spectra, (b) Fluorescence spectra of compound 3 in 10,50,70, and 90\% DMSO:0.01 M HEPES buffer solution $\left(\lambda_{\mathrm{ex}}=368 \mathrm{~nm}\right)$, Figure S9: (a), (b)Time-dependent fluorescence response and (c) pseudo-first-order kinetic plots of ABIA $(10 \mu \mathrm{M})$ reaction with Cys $(50 \mu \mathrm{M})$ in 90\% DMSO:0.01 M HEPES buffer solution $\left(\lambda_{\mathrm{ex}}=368 \mathrm{~nm}\right.$, 
$\left.\lambda_{\mathrm{em}}=455 \mathrm{~nm}\right)$, Figure S10: Mass spectra of a reaction product obtained by reacting equimolar ABIA and Cys for $60 \mathrm{~min}$ at $25{ }^{\circ} \mathrm{C}$, Table S1: ${ }^{1} \mathrm{H}$ NMR and ${ }^{13} \mathrm{C}$ NMR chemical shifts $(\delta \mathrm{ppm})$ of the ABIA tautomer's A and B, Table S1. ${ }^{1} \mathrm{H}$ NMR and ${ }^{13} \mathrm{C}$ NMR chemical shifts $(\delta \mathrm{ppm})$ of the ABIA tautomer's A and B; Table S2: Photophysical properties of compound $3(10 \mu \mathrm{M})$ in varying percentages of DMSO:0.01 M HEPES buffer solution, Table S3: A comparison of response time for cysteine detection by various methods, Table S4: A comparison of different probes used for cysteine detection.

Author Contributions: Conceptualization, S.B.N.; methodology, G.S.Y., I.-h.S., T.K., P.B.S., S.D.W., S.-m.P. and S.B.N.; software, T.K.; formal analysis, G.S.Y., I.-h.S., S.D.W., T.K. and S.B.N.; investigation, G.S.Y., I.-h.S., T.K., S.D.W. and S.-m.P.; data curation, G.S.Y., I.-h.S. and S.B.N.; writing-original draft preparation, G.S.Y. and S.B.N.; writing-review and editing, P.B.S., T.K. and S.B.N.; supervision, S.B.N.; project administration, P.B.S. and S.B.N.; funding acquisition, S.B.N. All authors have read and agreed to the published version of the manuscript.

Funding: Hallym University Research Fund (HRF-202012-009) supported this research.

Institutional Review Board Statement: Not applicable.

Informed Consent Statement: Not applicable.

Data Availability Statement: The data presented in this study are available upon request from the corresponding author.

Conflicts of Interest: The authors declare no conflict of interest.

\section{References}

1. Serpa, J. Cysteine as a Carbon Source, a Hot Spot in Cancer Cells Survival. Front. Oncol. 2020, 10, 947. [CrossRef] [PubMed]

2. Yu, L.; Teoh, S.T.; Ensink, E.; Ogrodzinski, M.P.; Yang, C.; Vazquez, A.I.; Lunt, S.Y. Cysteine catabolism and the serine biosynthesis pathway support pyruvate production during pyruvate kinase knockdown in pancreatic cancer cells. Cancer Metab. $2019,7,13$. [CrossRef] [PubMed]

3. Wu, G.; Fang, Y.-Z.; Yang, S.; Lupton, J.R.; Turner, N.D. Glutathione Metabolism and Its Implications for Health. J. Nutr. 2004, 134, 489-492. [CrossRef] [PubMed]

4. Liu, X.; Zhang, S.; Whitworth, R.J.; Stuart, J.J.; Chen, M.-S. Unbalanced Activation of Glutathione Metabolic Pathways Suggests Potential Involvement in Plant Defense against the Gall Midge Mayetiola destructor in Wheat. Sci. Rep. 2015, 5, 8092. [CrossRef]

5. Blom, H.J.; Smulders, Y. Overview of homocysteine and folate metabolism. With special references to cardiovascular disease and neural tube defects. J. Inherit. Metab. Dis. 2011, 34, 75-81. [CrossRef]

6. Hasan, T.; Arora, R.; Bansal, A.K.; Bhattacharya, R.; Sharma, G.S.; Singh, L.R. Disturbed homocysteine metabolism is associated with cancer. Exp. Mol. Med. 2019, 51, 1-13. [CrossRef]

7. Daher, B.; Vučetić, M.; Pouysségur, J. Cysteine Depletion, a Key Action to Challenge Cancer Cells to Ferroptotic Cell Death. Front. Oncol. 2020, 10, 723. [CrossRef]

8. Dröge, W. Oxidative stress and ageing: Is ageing a cysteine deficiency syndrome? Philos. Trans. R. Soc. B Biol. Sci. 2005, 360, 2355-2372. [CrossRef]

9. Rehman, T.; Shabbir, M.A.; Inam-Ur-Raheem, M.; Manzoor, M.F.; Ahmad, N.; Liu, Z.-W.; Ahmad, M.H.; Siddeeg, A.; Abid, M.; Aadil, R.M. Cysteine and homocysteine as biomarker of various diseases. Food Sci. Nutr. 2020, 8, 4696-4707. [CrossRef]

10. Rhodes, H.L.; Yarram-Smith, L.; Rice, S.J.; Tabaksert, A.; Edwards, N.; Hartley, A.; Woodward, M.N.; Smithson, S.L.; Tomson, C.; Welsh, G.I.; et al. Clinical and Genetic Analysis of Patients with Cystinuria in the United Kingdom. Clin. J. Am. Soc. Nephrol. 2015, 10, 1235. [CrossRef]

11. Otter, D.E. Standardised methods for amino acid analysis of food. Br. J. Nutr. 2012, 108, S230-S237. [CrossRef]

12. Maheshwari, H.; Vilà, N.; Herzog, G.; Walcarius, A. Selective Detection of Cysteine at a Mesoporous Silica Film Electrode Functionalized with Ferrocene in the Presence of Glutathione. ChemElectroChem 2020, 7, 2095-2101. [CrossRef]

13. Jongjinakool, S.; Palasak, K.; Bousod, N.; Teepoo, S. Gold Nanoparticles-based Colorimetric Sensor for Cysteine Detection. Energy Procedia 2014, 56, 10-18. [CrossRef]

14. Tajik, S.; Dourandish, Z.; Jahani, P.M.; Sheikhshoaie, I.; Beitollahi, H.; Shahedi Asl, M.; Jang, H.W.; Shokouhimehr, M. Recent developments in voltammetric and amperometric sensors for cysteine detection. RSC Adv. 2021, 11, 5411-5425. [CrossRef]

15. Han, C.; Yang, H.; Chen, M.; Su, Q.; Feng, W.; Li, F. Mitochondria-Targeted Near-Infrared Fluorescent Off-On Probe for Selective Detection of Cysteine in Living Cells and in Vivo. ACS Appl. Mater. Interfaces 2015, 7, 27968-27975. [CrossRef]

16. Yang, Z.; Cao, J.; He, Y.; Yang, J.H.; Kim, T.; Peng, X.; Kim, J.S. Macro-/micro-environment-sensitive chemosensing and biological imaging. Chem. Soc. Rev. 2014, 43, 4563-4601. [CrossRef]

17. Chan, J.; Dodani, S.C.; Chang, C.J. Reaction-based small-molecule fluorescent probes for chemoselective bioimaging. Nat. Chem. 2012, 4, 973-984. [CrossRef]

18. Zhou, M.; Ding, J.; Guo, L.-P.; Shang, Q.-K. Electrochemical Behavior of 1-Cysteine and Its Detection at Ordered Mesoporous Carbon-Modified Glassy Carbon Electrode. Anal. Chem. 2007, 79, 5328-5335. [CrossRef] 
19. Zhang, W.; Zhao, X.; Gu, W.; Cheng, T.; Wang, B.; Jiang, Y.; Shen, J. A novel naphthalene-based fluorescent probe for highly selective detection of cysteine with a large Stokes shift and its application in bioimaging. New J. Chem. 2018, 42, 18109-18116. [CrossRef]

20. Fu, Z.-H.; Han, X.; Shao, Y.; Fang, J.; Zhang, Z.-H.; Wang, Y.-W.; Peng, Y. Fluorescein-Based Chromogenic and Ratiometric Fluorescence Probe for Highly Selective Detection of Cysteine and Its Application in Bioimaging. Anal. Chem. 2017, 89, 1937-1944. [CrossRef]

21. Dong, B.; Lu, Y.; Zhang, N.; Song, W.; Lin, W. Ratiometric Imaging of Cysteine Level Changes in Endoplasmic Reticulum during H2O2-Induced Redox Imbalance. Anal. Chem. 2019, 91, 5513-5516. [CrossRef]

22. Yu, S.; Nimse, S.B.; Kim, J.; Song, K.-S.; Kim, T. Development of a Lateral Flow Strip Membrane Assay for Rapid and Sensitive Detection of the SARS-CoV-2. Anal. Chem. 2020, 92, 14139-14144. [CrossRef]

23. Tang, B.; Xing, Y.; Li, P.; Zhang, N.; Yu, F.; Yang, G. A Rhodamine-Based Fluorescent Probe Containing a Se-N Bond for Detecting Thiols and Its Application in Living Cells. J. Am. Chem. Soc. 2007, 129, 11666-11667. [CrossRef]

24. Yuan, L.; Lin, W.; Zhao, S.; Gao, W.; Chen, B.; He, L.; Zhu, S. A Unique Approach to Development of Near-Infrared Fluorescent Sensors for in Vivo Imaging. J. Am. Chem. Soc. 2012, 134, 13510-13523. [CrossRef]

25. Yang, X.; Guo, Y.; Strongin, R.M. Conjugate Addition/Cyclization Sequence Enables Selective and Simultaneous Fluorescence Detection of Cysteine and Homocysteine. Angew. Chem. Int. Ed. 2011, 50, 10690-10693. [CrossRef]

26. Long, Y.-T.; Kong, C.; Li, D.-W.; Li, Y.; Chowdhury, S.; Tian, H. Ultrasensitive Determination of Cysteine Based on the Photocurrent of Nafion-Functionalized CdS-MV Quantum Dots on an ITO Electrode. Small 2011, 7, 1624-1628. [CrossRef]

27. Wang, S.; Zhang, Q.; Chen, S.; Wang, K.-P.; Hu, Z.-Q. A diazabenzoperylene derivative as ratiometric fluorescent probe for cysteine with super large Stokes shift. Anal. Bioanal. Chem. 2020, 412, 2687-2696. [CrossRef]

28. Lim, S.; Escobedo, J.O.; Lowry, M.; Xu, X.; Strongin, R. Selective fluorescence detection of cysteine and N-terminal cysteine peptide residues. Chem. Commun. 2010, 46, 5707-5709. [CrossRef]

29. He, L.; Yang, X.; Xu, K.; Lin, W. Improved Aromatic Substitution-Rearrangement-Based Ratiometric Fluorescent Cysteine-Specific Probe and Its Application of Real-Time Imaging under Oxidative Stress in Living Zebrafish. Anal. Chem. 2017, 89, 9567-9573. [CrossRef]

30. Liu, B.; Wang, J.; Zhang, G.; Bai, R.; Pang, Y. Flavone-Based ESIPT Ratiometric Chemodosimeter for Detection of Cysteine in Living Cells. ACS Appl. Mater. Interfaces 2014, 6, 4402-4407. [CrossRef]

31. Zhou, J.; Yu, C.; Li, Z.; Peng, P.; Zhang, D.; Han, X.; Tang, H.; Wu, Q.; Li, L.; Huang, W. A rapid and highly selective paper-based device for high-throughput detection of cysteine with red fluorescence emission and a large Stokes shift. Anal. Methods 2019, 11, 1312-1316. [CrossRef]

32. Di Nonno, S.; Ulber, R. Smartphone-based optical analysis systems. Analyst 2021, 146, 2749-2768. [CrossRef] [PubMed]

33. Shariati, S.; Khayatian, G. The colorimetric and microfluidic paper-based detection of cysteine and homocysteine using 1,5-diphenylcarbazide-capped silver nanoparticles. RSC Adv. 2021, 11, 3295-3303. [CrossRef]

34. Mehta, S.M.; Mehta, S.; Muthurajan, H.; D'Souza, J.S. Vertical flow paper-based plasmonic device for cysteine detection. Biomed. Microdevices 2019, 21, 55. [CrossRef]

35. Ma, W.-W.; Wang, M.-Y.; Yin, D.; Zhang, X. Facile preparation of naphthol AS-based fluorescent probe for highly selective detection of cysteine in aqueous solution and its imaging application in living cells. Sens. Actuators B Chem. 2017, 248, 332-337. [CrossRef]

36. Long, G.L.; Winefordner, J.D. Limit of Detection A Closer Look at the IUPAC Definition. Anal. Chem. 1983, 55, 712A-724A. [CrossRef]

37. Lee, J.-S.; Warkad, S.D.; Shinde, P.B.; Kuwar, A.; Nimse, S.B. A highly selective fluorescent probe for nanomolar detection of ferric ions in the living cells and aqueous media. Arab. J. Chem. 2020, 13, 8697-8707. [CrossRef]

38. Song, I.-H.; Torawane, P.; Lee, J.-S.; Warkad, S.D.; Borase, A.; Sahoo, S.K.; Nimse, S.B.; Kuwar, A. The detection of $\mathrm{Al}^{3+}$ and Cu ${ }^{2+}$ ions using isonicotinohydrazide-based chemosensors and their application to live-cell imaging. Mater. Adv. 2021, 2, 6306-6314. [CrossRef]

39. Yaragorla, S.; Vijaya Babu, P. Oxidative Csp3-H functionalization of 2-methylazaarenes: A practical synthesis of 2-azaarenylbenzimidazoles and benzothiazoles. Tetrahedron Lett. 2017, 58, 1879-1882. [CrossRef]

40. Baig, M.F.; Shaik, S.P.; Nayak, V.L.; Alarifi, A.; Kamal, A. Iodine-catalyzed Csp3-H functionalization of methylhetarenes: Onepot synthesis and cytotoxic evaluation of heteroarenyl-benzimidazoles and benzothiazole. Bioorganic Med. Chem. Lett. 2017, 27, 4039-4043. [CrossRef]

41. Kadri, H.; Matthews, C.S.; Bradshaw, T.D.; Stevens, M.F.; Westwell, A.D. Synthesis and antitumour evaluation of novel 2-phenylbenzimidazoles. J. Enzyme Inhib. Med. Chem. 2008, 23, 641-647. [CrossRef]

42. Lee, I.-S.H.; Jeoung, E.H.; Lee, C.K. Synthesis and tautomerism of 2-aryl- and 2-heteroaryl derivatives of benzimidazole. J. Heterocycl. Chem. 1996, 33, 1711-1716. [CrossRef]

43. Dai, Y.; Zheng, Y.; Xue, T.; He, F.; Ji, H.; Qi, Z. A novel fluorescent probe for rapidly detection cysteine in cystinuria urine, living cancer/normal cells and BALB/c nude mice. Spectrochim. Acta Part A Mol. Biomol. Spectrosc. 2020, 225, 117490. [CrossRef]

44. Toro-Roman, V.; Siquier-Coll, J.; Bartolome, I.; Grijota, F.J.; Munoz, D.; Maynar-Marino, M. Copper concentration in erythrocytes, platelets, plasma, serum and urine: Influence of physical training. J. Int. Soc. Sports Nutr. 2021, 18, 28. [CrossRef]

45. Kaniowska, E.; Chwatko, G.; Glowacki, R.; Kubalczyk, P.; Bald, E. Urinary excretion measurement of cysteine and homocysteine in the form of their S-pyridinium derivatives by high-performance liquid chromatography with ultraviolet detection. J. Chromatogr. A 1998, 798, 27-35. [CrossRef]

46. Zelikovic, I. Chapter 19-Hereditary Tubulopathies. In Nephrology and Fluid/electrolyte Physiology, 3rd ed.; Oh, W., Baum, M., Eds.; Elsevier: Philadelphia, PA, USA, 2019; pp. 315-344.

47. Rusin, O.; St Luce, N.N.; Agbaria, R.A.; Escobedo, J.O.; Jiang, S.; Warner, I.M.; Dawan, F.B.; Lian, K.; Strongin, R.M. Visual Detection of Cysteine and Homocysteine. J. Am. Chem. Soc. 2004, 126, 438-439. [CrossRef] 
48. Xu, Y.; Li, B.; Han, P.; Sun, S.; Pang, Y. Near-infrared fluorescent detection of glutathione via reaction-promoted assembly of squaraine-analyte adducts. Analyst 2013, 138, 1004-1007. [CrossRef]

49. Wei, M.; Yin, P.; Shen, Y.; Zhang, L.; Deng, J.; Xue, S.; Li, H.; Guo, B.; Zhang, Y.; Yao, S. A new turn-on fluorescent probe for selective detection of glutathione and cysteine in living cells. Chem. Commun. 2013, 49, 4640-4642. [CrossRef]

50. Chen, Z.; Sun, Q.; Yao, Y.; Fan, X.; Zhang, W.; Qian, J. Highly sensitive detection of cysteine over glutathione and homo-cysteine: New insight into the Michael addition of mercapto group to maleimide. Biosens. Bioelectron. 2017, 91, 553-559. [CrossRef]

51. Wang, P.; Liu, J.; Lv, X.; Liu, Y.; Zhao, Y.; Guo, W. A Naphthalimide-Based Glyoxal Hydrazone for Selective Fluorescence Turn-On Sensing of Cys and Hcy. Org. Lett. 2012, 14, 520-523. [CrossRef]

52. Zhang, J.; Wang, J.; Liu, J.; Ning, L.; Zhu, X.; Yu, B.; Liu, X.; Yao, X.; Zhang, H. Near-Infrared and Naked-Eye Fluorescence Probe for Direct and Highly Selective Detection of Cysteine and Its Application in Living Cells. Anal. Chem. 2015, 87, 4856-4863. [CrossRef]

53. Sun, Q.; Yang, S.-H.; Wu, L.; Yang, W.-C.; Yang, G.-F. A Highly Sensitive and Selective Fluorescent Probe for Thiophenol Designed via a Twist-Blockage Strategy. Anal. Chem. 2016, 88, 2266-2272. [CrossRef]

54. Bugaenko, D.I.; Karchava, A.V.; Yunusova, Z.A.; Yurovskaya, M.A. Fluorescent probes on the basis of coumarin derivatives for determining biogenic thiols and thiophenols. Chem. Heterocycl. Compd. 2019, 55, 483-489. [CrossRef]

55. Cao, D.; Liu, Z.; Verwilst, P.; Koo, S.; Jangjili, P.; Kim, J.S.; Lin, W. Coumarin-Based Small-Molecule Fluorescent Chemosensors. Chem. Rev. 2019, 119, 10403-10519. [CrossRef]

56. Liu, G.; Liu, D.; Han, X.; Sheng, X.; Xu, Z.; Liu, S.H.; Zeng, L.; Yin, J. A hemicyanine-based colorimetric and ratiometric fluorescent probe for selective detection of cysteine and bioimaging in living cell. Talanta 2017, 170, 406-412. [CrossRef]

57. Qi, Y.; Huang, Y.; Li, B.; Zeng, F.; Wu, S. Real-Time Monitoring of Endogenous Cysteine Levels In Vivo by near-Infrared Turn-on Fluorescent Probe with Large Stokes Shift. Anal. Chem. 2018, 90, 1014-1020. [CrossRef]

58. Tang, L.; Shi, J.; Huang, Z.; Yan, X.; Zhang, Q.; Zhong, K.; Hou, S.; Bian, Y. An ESIPT-based fluorescent probe for selective detection of homocysteine and its application in live-cell imaging. Tetrahedron Lett. 2016, 57, 5227-5231. [CrossRef]

59. Odyniec, M.L.; Park, S.-J.; Gardiner, J.E.; Webb, E.C.; Sedgwick, A.C.; Yoon, J.; Bull, S.D.; Kim, H.M.; James, T.D. A fluorescent ESIPT-based benzimidazole platform for the ratiometric two-photon imaging of ONOO-In vitro and ex vivo. Chem. Sci. 2020, 11, 7329-7334. [CrossRef]

60. Sharma, S.; Pradeep, C.P.; Dhir, A. Benzimidazole Based ‘Turn on' Fluorescent Chemodosimeter for Zinc Ions in Mixed Aqueous Medium. J. Fluoresc. 2016, 26, 1439-1445. [CrossRef] 